\title{
DIFFERENT TILLAGE OPTIONS AND RESIDUE MANAGEMENT FOR IMPROVINGCROP PRODUCTIVITY AND SOIL FERTILITY IN WHEAT-MAIZE-RICE CROPPING PATTERN
}

\author{
M.I. Hossain ${ }^{1}$, M.I. Hossain ${ }^{2}$, M.A. Ohab ${ }^{3}$, M.H.R. Sheikh ${ }^{4}$ and B.L. $\mathrm{Nag}^{5}$ \\ ${ }^{1}$ Principal Scientific Officer, Regional Station, BWMRI, Rajshahi, ${ }^{2}$ Director General, BWMRI, Nashipur, Dinajpur, \\ ${ }^{3 \& 4}$ Director (Planning) \& Director (Research), BARI, Gazipur \\ Corresponding E-mail: iliasrwrc@gmail.com
}

(Received: 29 December 2019, Accepted: 18 March 2020)

Keywords: Conservation tillage, residue retention, crop productivity, soil fertility and cropping pattern

\begin{abstract}
A three yearsfield experiment was conducted at Regional Wheat Research Centre, Shyampur, Rajshahiduring 2014-15 to 2017-18 with an objective to observe the effects on soil fertility and performance of the crops under different tillage and residue management for rice-wheat (RW) systems by adding a third pre-rice crop of maize. The experiment was conducted in split plot design with three replication. The tillage options viz. (i) Strip tillage (ST) (ii) Permanent bed (PB) and (iii) conventional (CT) tillage; two crop residue management, viz. (i) $0 \%=$ no residue and (ii) $30 \%$ residue retention were studied. The results indicated that keeping 30\% crop residue in the field with minimum disturbance of soil had significant contribution on grain yield of wheat-maize-rice sequence compare to conventional practice of well-till without crop residue retention. The permanent bed planting system gave the highest yields of wheat $\left(4.37 \mathrm{tha}^{-1}\right)$, maize $\left(7.31 \mathrm{tha}^{-1}\right)$ and rice $\left(4.40\right.$ tha $\left.^{-1}\right)$ and followed by strip tillage and lowest in conventional tillage. Among the residue management, $30 \%$ residue retention showed the highest yields of wheat (4.46tha $\left.{ }^{1}\right)$, maize $\left(7.39\right.$ tha $\left.^{-1}\right)$ and rice $\left(4.69\right.$ tha $\left.^{-1}\right)$. Considering economic performance of all tillage systems, the permanent bed planting system performed the best among all other tillage options and followed by strip tillage. Contrarily, 30\% residue retention gave the highest yield and increased $0.12-0.14 \%$ organic matter into the soil with more productive. The results indicates that, both tillage systems coupled with $30 \%$ residue retention might be a good option for higher yield as well as soil fertility for Wheat-MaizeTaman rice cropping pattern in drought prone areas of Bangladesh.
\end{abstract}

\section{Introduction}

Crop production under permanent raised bed with residue retention is one of the best technologies for resource conservation in agriculture. Upland crops like wheat and maize were established and grown successfully in permanent raised bed with wheat-maize-rice cropping pattern. Land degradation and soil fertility decline are the main causes of the stagnation which reduces the agricultural production in many tropical countries, including those with intensive irrigated cropping systems. Rice is transplanted in flat fields are typically ponded for long periods or continuously from transplanting until shortly before harvest. This negatively affects soil properties for the following non-puddled crop (Hobbs and Giri, 1998). A change from growing crops on the flat to raised beds offers more effective control of irrigation water and drainage. Connor et al. (2002) suggested that permanent raised beds might offer farmers further significant advantages such as increased opportunities for crop diversification, mechanical weeding and placement of fertilizers; relay cropping and inter-cropping; and reduced tillage and water saving. Raised beds are increasingly used in many developed and developing countries in 
mechanized agriculture but have been introduced recently in Bangladesh, with the aim of improving system productivity (Talukderet al., 2002).

Inclusion of maize in the dry-wet transition of rice-wheat (RW) cropping system as a third crop may be another options of increasing cropping intensity, soil fertility and productivity of the system. Although the non-rice season across the rice-wheat area is low rainfall, heavy pre-monsoonal rain can have disastrous effects on the third crop, such as maize or mungbean grown after wheat or before rice, both during establishment and grain filling because of water logging (Timsina and Connor, 2001; Quayyumet al., 2002). Due to lack of crop establishment technique and temporary water logging at reproductive stage, inclusion of a grain legume like mungbean in rice-wheat cropping system very often faces problems. Bed planting may be a solution of this problem because raised beds not only facilitates irrigation but also drainage and therein lays their potential to increase the productivity of crops other than rice in the system. Growing maize crops in a cropping system is beneficial not only for economic products but also for soil amelioration (Singh and Singh,1995). The common practice of rice in puddle soils destroys the soil physical structure that has implications for the following wheat crop (Hobbs and Gupta, 2000).

Crop residues are an important source of soil organic matter vital for the sustainability of agricultural ecosystems. About $25 \%$ of $\mathrm{N}$ and $\mathrm{P}, 50 \%$ of $\mathrm{S}$ and $75 \%$ of $\mathrm{K}$ uptake by cereal crops is retained in crop residues, making them valuable nutrient sources (Singh, 2003). However, straw retention is not a common practice in the RW systems of Bangladesh. Wheat and rice straw are usually removed from fields for use as cattle feed and thatching material for houses or for fuel, leaving little for incorporation into the soil. Gupta et al. (2002) observed that soil organic matter levels have declined in rice-wheat cropping systems, and optimization of nutrient uptake and absorption efficiency. Limon-Ortega et al. (2000) observed that permanent beds with straw retention had the highest mean wheat grain yields with positive implications for soil health. Thus, management of crop residue and proper tillage options which may increase and maintain yields from the intensive RW system in Bangladesh. Therefore, this study was undertaken in a drought prone area in north-western part at Rajshahi to evaluate the system productivity and soil property of intensive wheat-maize-rice crops sequence tested on CA practice compared to conventionally tilled systems.

\section{Materials and Methods}

A wheat-maize-rice cropping pattern was implemented whereas starting with wheat sown in November 25, 2014 and November 27, 2015 for wheat, maize crop sown on 3 April 2014 and transplanting rice on 27 July 2014 at the Regional Wheat Research Centre, Shyampur (RWRC), Rajshahi, Bangladesh $\left(24^{\circ} 3^{\prime} \mathrm{N}, 88^{\circ} 41 \mathrm{E}, 18 \mathrm{~m}\right.$ above sea level). The site has a subtropical climate and is located in Agro ecological Zone 11 (High Ganges River Flood Plan) on flood-free high land, with course-textured, highly permeable soil (BARC, 2012). The area receives $1072 \mathrm{~mm}$ mean annual rainfall, about $95 \%$ of which occurs from May to September (Figure 1). 


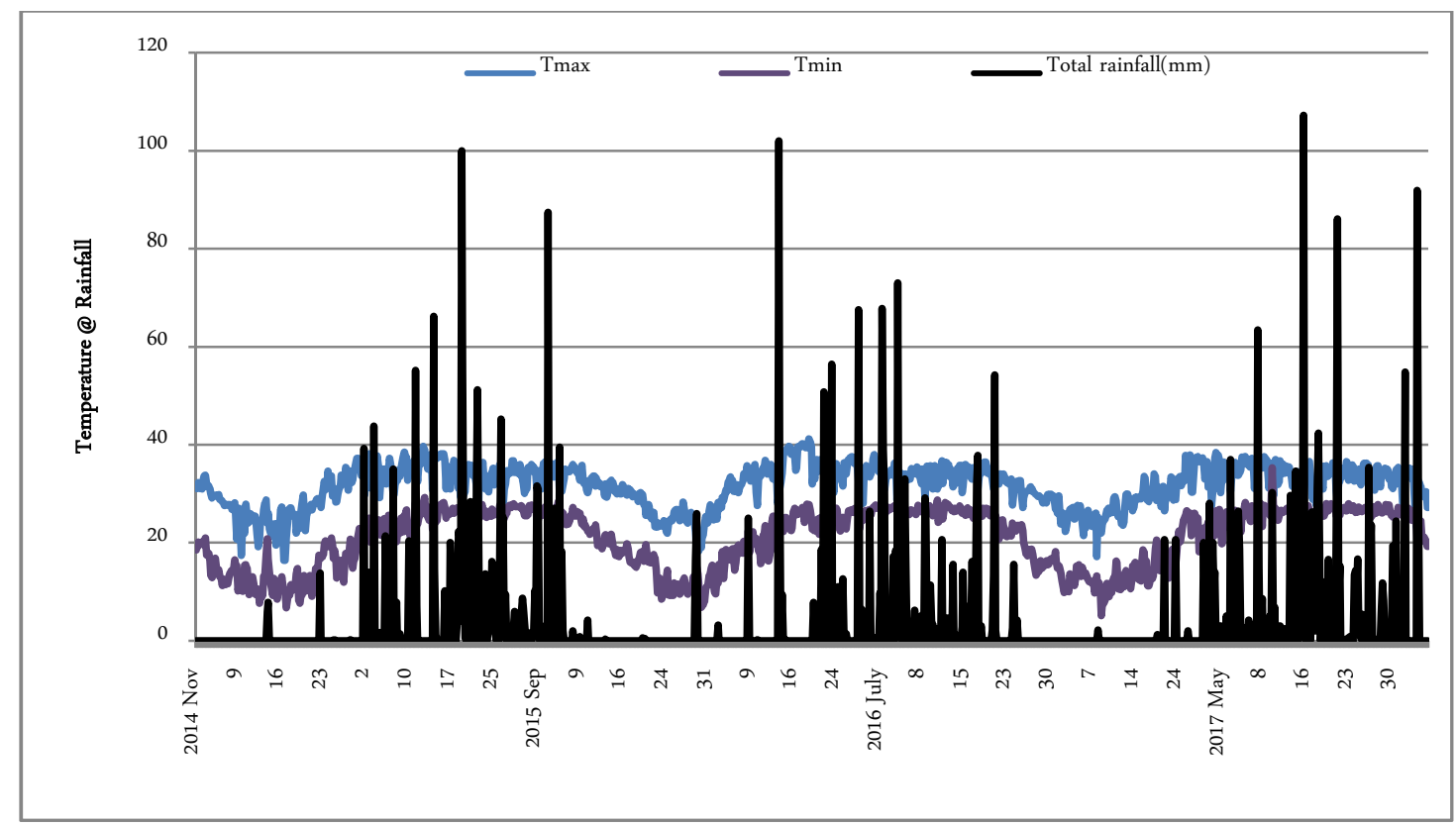

Fig. 1. Weather data from Nov 2014 to Oct 2017

The trial involved a three-crop sequence i,e., rice-wheat-maize (RWM) planted on permanent raised beds (PB), fresh bed (FB) and conventional flats. Rice was transplanted (one 25-days-old seedling per hill) with spacing $30 \mathrm{~cm} \times 15 \mathrm{~cm}$ in late July and harvested in late November by hand. Wheat was seeded at late November with 100 and $120 \mathrm{~kg}$ seed $\mathrm{ha}^{-1}$ for both raised beds and conventional flat, respectively and harvested in late March. After harvest of wheat, maize was planted in early April with seeding rate of $20 \mathrm{~kg} \mathrm{ha}^{-1}$ and harvested in mid-July for both raised beds and conventional. The trial was originally established as $\mathrm{PB}, \mathrm{FB}$ and conventional practices with two straw management (main plots-30\% straw retention (SR) and $0 \% \mathrm{SR}$ ). The experiments were conducted on split plot design with three replication. The area of each subplot was $15 \mathrm{~m}^{2}(5 \mathrm{~m} \times 3 \mathrm{~m})$. The experiment consisted of 6 subplots with three tillage/straw treatments $(30 \% \mathrm{SR}+\mathrm{PB}, 30 \% \mathrm{SR}+\mathrm{CTP}, 30 \% \mathrm{SR}+\mathrm{ST}$ and $0 \% \mathrm{SR}$ $+\mathrm{CTP}, 0 \% \mathrm{SR}+\mathrm{PB}$ and $0 \% \mathrm{SR}+\mathrm{ST}$ ) with three replication. After planting the wheat or rice, straw from the preceding cereal crops was returned as mulch into the plot from which it had been removed at harvest. After harvesting and threshing, the rice and wheat straw were retained without chopping as standing way.

The width of the beds was $60 \mathrm{~cm}$ (furrow to furrow) and the depth of the furrows on average was 15 $\mathrm{cm}$. Two rows of wheat (var. BARI Gom-30) or rice (var. BRRI dhan71) with a spacing of $30 \mathrm{~cm}$, were planted by hand sowing on the beds, maize (var. NK-40) was sown by bed former in the furrows between the beds and indicator plant to assess microbial activity in the soil environment. The maize was harvested about 120 days after sowing (DAS). In CTP, wheat, rice and maize were planted in 20 $\mathrm{cm}, 30 \times 15 \mathrm{~cm}$ (row x plant) and $60 \mathrm{~cm}$ rows, respectively. A basal dose of P (20, 22 and $\left.26 \mathrm{~kg} \mathrm{ha}^{-1}\right)$ from triple super phosphate, $\mathrm{K}\left(15,33\right.$ and $\left.35 \mathrm{~kg} \mathrm{ha}^{-1}\right)$ from muriate of potash and $\mathrm{S}(10,11$ and $20 \mathrm{~kg}$ $\mathrm{ha}^{-1}$ ) from gypsum was applied to rice, wheat and maize, respectively. In rice the entire amount of PKS was broadcast before transplanting and mulching on both PRB and CTP. For CTP the fertilizer was broadcast before tillage as is the usual practice. The recommended rate of $\mathrm{N}\left(80 \mathrm{~kg} \mathrm{ha}^{-1}\right.$ for rice, $100 \mathrm{~kg}$ $\mathrm{ha}^{-1}$ for wheat and $210 \mathrm{~kg} \mathrm{ha}^{-1}$ for maize) was applied as urea. With CTP, N was broadcast, while with beds it was banded on top of the soil between two rows in three equal installments 15, 30 and 45 days after transplanting of rice seedling, while wheat, two-thirds of the $\mathrm{N}$ was applied before seeding and the 
remaining one-third at crown root initiation (CRI). In maize, one-third $\mathrm{N}$ was applied as urea before seeding, one-third at eight leaves stage and remaining one-third at flowering stage. Other fertilizers were applied before seeding in all three crops as recommended said doses.

Sufficient irrigation water was applied to fill the furrows between the raised beds. The flat plots were flood irrigated. Weed control was done after the first irrigation for wheat by Affinity application @ $2 \mathrm{~g}$ litre- ${ }^{1}$ of water, and at 25 and 45 days after transplanting for rice by Ronstar@1 $1 \mathrm{ml}$ litre- ${ }^{1}$ of water. Grain and straw yield were determined on a $5 \mathrm{~m}^{2}$ areas in each plot.

\section{Statistical analysis of data}

The data were analyzed statistically following computer package MSTATC and the significance of mean differences was adjusted by Duncan's Multiple Range Test (DMRT) at P $\leq 0.05$ (Gomez and Gomez, 1984).

\section{Results and Discussion}

Before experimentation initial soil sample was collected and analyzed to know the nutrient status and the results were presented in Table1. The soil was slightly alkaline $(\mathrm{pH} 7.8)$ havingvery low organic matter content $(0.94 \%)$ and nitrogen, and zinccontent. The overall soil fertility status was low.

Table1. Fertility status of initial soil sample of the experimental site at RWRC, BARI, Rajshahi

\begin{tabular}{|c|c|c|c|c|c|c|c|c|}
\hline Sample & $\mathrm{pH}$ & OM (\%) & Total N & $\mathrm{K}$ & $\mathrm{P}$ & $\mathrm{S}$ & $\mathrm{Zn}$ & B \\
\hline & & & $(\%)$ & Meq100g- & \multicolumn{4}{|c|}{$\mu g g-$} \\
\hline Value & 7.8 & 0.94 & 0.05 & 0.21 & 10 & 23.3 & 0.14 & 0.27 \\
\hline Critical level & - & - & 0.12 & 0.12 & 10 & 10.0 & 0.60 & 0.20 \\
\hline Interpretation & $\begin{array}{l}\text { Slightly } \\
\text { Alkaline }\end{array}$ & $\begin{array}{l}\text { Very } \\
\text { low }\end{array}$ & Very low & Medium & Low & Opt. & $\begin{array}{l}\text { Very } \\
\text { low }\end{array}$ & low \\
\hline
\end{tabular}

\section{Grain yield and yield components of wheat}

Grain yield is the cumulative effect of spike $\mathrm{m}^{-2}$, grains spike ${ }^{-1}$ and 1000 grain weight. Yield and yield components data were shown in Table 2. Straw management were significantly influenced on grain yield and yield attributes in all three years but straw retention did not give any significant effect on spike $\mathrm{m}^{2}$ and spikelet spike- ${ }^{1}$. The average three years maximum grain yield $\left(4.40 \mathrm{t} \mathrm{ha}^{-1}\right)$ was found from $30 \%$ straw retention plotover without straw retention plotin all three years. Hobbs et al.(2000) found similar findings from their same experiments..

Table 2. Effect of straw management on yield and yield components of wheat in 2014-15 to 2016-17

\begin{tabular}{lccccccccc}
\hline $\begin{array}{c}\text { Straw } \\
\text { management }\end{array}$ & $\begin{array}{c}\text { Spikes } \\
\mathrm{m}^{-2}\end{array}$ & $\begin{array}{c}\text { Spikelet } \\
\text { Spike }^{-1}\end{array}$ & $\begin{array}{c}\text { Grains } \\
\text { Spike }^{-1}\end{array}$ & $\begin{array}{c}\text { TGW } \\
(\mathrm{g})\end{array}$ & & \multicolumn{2}{c}{ Grain yield $\left(\mathrm{t} \mathrm{ha}{ }^{-1}\right)$} & \multicolumn{2}{c}{$\begin{array}{c}\text { Av. 3 years } \\
\text { yield } \\
\left(\mathrm{t} \mathrm{ha}^{-1}\right)\end{array}$} \\
\cline { 6 - 10 } & & & & & $2014-15$ & $2015-16$ & $2016-17$ & \\
\hline 0\% Straw & 373 & 17.7 & 43.7 & 48.6 & 4.17 & 3.89 & 4.12 & 4.06 \\
30\% Straw & 372 & 18.4 & 50.6 & 53.9 & 4.60 & 4.39 & 4.48 & 4.46 \\
\hline T Test & $\mathrm{ns}$ & $\mathrm{ns}$ & $* *$ & $* *$ & $* *$ & $* *$ & $* *$ & $* *$ \\
\hline
\end{tabular}

\section{Grain yield and yield components of wheat}

Grain yield is the cumulative effect of spike $\mathrm{m}^{-2}$, grains spike ${ }^{-1}$ and 1000 grain weight. Yield and yield components data were shown in Table 3 . Tillage systems were significantly influenced on grain yield and yield attributes in all three years but straw retention did not give any significant effect on yield and yield components. But strip till and permanent bed system did not any significant effect in all three 
years on wheat. The average three years maximum grain yield $\left(4.40 \mathrm{tha}^{-1}\right)$ was found from strip till system and it was at par with Permanent beds $\left(4.37 \mathrm{t} \mathrm{ha}^{-1}\right)$ was found from all three years. Hobbs et al.(2000)found similar findings from their same experiments. The lowest yield was also found from conventional practices in both the years. Grain yield was higher due to higher yield attributes and get more photosynthesis with border effect. The minimum yield $\left(4.07 \mathrm{t} \mathrm{ha}^{-1}\right)$ was found from conventional tillage practice due to lower yield components and less photosynthesis with border effect. Kataki(2001) found similar findings from both tillage options in wheat

Table 3. Effect of tillage options on yield and yield components of wheat in 2014-15 to 2016-17

\begin{tabular}{|c|c|c|c|c|c|c|c|c|}
\hline \multirow{2}{*}{$\begin{array}{l}\text { Tillage } \\
\text { options }\end{array}$} & \multirow{2}{*}{$\begin{array}{c}\text { Spikes } \\
\mathrm{m}^{-2}\end{array}$} & \multirow{2}{*}{$\begin{array}{l}\text { Spikelet } \\
\text { Spike }^{-1}\end{array}$} & \multirow{2}{*}{$\begin{array}{l}\text { Grains } \\
\text { Spike }^{-1}\end{array}$} & \multirow{2}{*}{$\begin{array}{c}\text { TGW } \\
(\mathrm{g})\end{array}$} & \multicolumn{3}{|c|}{ Grain yield $\left(\mathrm{t} \mathrm{ha}^{-1}\right)$} & \multirow{2}{*}{$\begin{array}{c}\text { Av. } 3 \\
\text { years } \\
\text { yield } \\
\left(\mathrm{t} \mathrm{ha}^{-1}\right) \\
\end{array}$} \\
\hline & & & & & $2014-15$ & $2015-16$ & $2016-17$ & \\
\hline Conventional & 368 & 17.2 & 43.2 & 49.6 & 4.07 & 3.62 & 3.78 & 3.82 \\
\hline $\begin{array}{l}\text { Permanent } \\
\text { bed }\end{array}$ & 352 & 18.8 & 50.3 & 54.9 & 4.62 & 4.19 & 4.31 & 4.37 \\
\hline Strip tillage & 357 & 18.5 & 50.8 & 54.7 & 4.68 & 4.17 & 4.35 & 4.40 \\
\hline CV (\%) & 13.14 & 5.34 & 7.59 & 3.65 & 12.44 & 8.745 & 9.15 & 7.65 \\
\hline $\operatorname{LSD}_{(0.05)}$ & ns & ns & 2.034 & 1.032 & 0.135 & 0.121 & 0.231 & 0.231 \\
\hline
\end{tabular}

\section{Wheat grain yield and components under tillage options with residue management}

Residue management with tillage systems was significantly influenced among the grain yield and yield components. Grain yield is the cumulative effect of spike $\mathrm{m}^{-2}$, grains spike ${ }^{-1}$ and 1000 grain weight. Average three years yield data were shown in Table 4. The maximum grain yield was found $\left(4.37 \mathrm{t} \mathrm{ha}^{-}\right.$ ${ }^{1}$ ) was found from $30 \%$ residue retention with strip till systems and it was at par with $\left(4.34 \mathrm{t} \mathrm{ha}^{-1}\right)$ permanent bed system with $30 \%$ residue retention.

Table 4. Interaction effect of tillage options and straw management on grain yield and yield attributes of wheat in 2014-15 to 2016-17

\begin{tabular}{|c|c|c|c|c|c|c|c|c|}
\hline \multirow{2}{*}{$\begin{array}{l}\text { Tillage options } \\
\text { x N levels }\end{array}$} & \multirow{2}{*}{$\begin{array}{l}\text { Spikes } \\
\mathrm{m}^{-2}\end{array}$} & \multirow{2}{*}{$\begin{array}{l}\text { Spikelet } \\
\text { Spike }^{-1}\end{array}$} & \multirow{2}{*}{$\begin{array}{l}\text { Grains } \\
\text { Spike }^{-1}\end{array}$} & \multirow{2}{*}{$\begin{array}{l}\text { TGW } \\
(\mathrm{g})\end{array}$} & \multicolumn{3}{|c|}{ Grain yield $\left(\mathrm{t} \mathrm{ha}^{-1}\right)$} & \multirow{2}{*}{$\begin{array}{r}\text { Av. } 3 \\
\text { years } \\
\text { yield } \\
\left(\mathrm{t} \mathrm{ha}^{-1}\right)\end{array}$} \\
\hline & & & & & $2014-15$ & $2015-16$ & 2016-17 & \\
\hline Conv. x $0 \%$ SR & 311 & 17.2 & 48.2 & 53.5 & 3.87 & 3.42 & 3.53 & 3.61 \\
\hline Conv. x $30 \% \mathrm{SR}$ & 329 & 18.7 & 51.5 & 54.7 & 4.04 & 3.61 & 3.78 & 3.81 \\
\hline PB x $0 \%$ SR & 317 & 17.7 & 48.4 & 53.4 & 4.24 & 4.03 & 4.12 & 4.13 \\
\hline $\mathrm{PB} \times 30 \% \mathrm{SR}$ & 321 & 18.7 & 52.4 & 54.5 & 4.41 & 4.21 & 4.41 & 4.34 \\
\hline ST x $0 \% \mathrm{SR}$ & 319 & 17.8 & 49.2 & 52.6 & 4.38 & 4.07 & 4.19 & 4.21 \\
\hline ST x $30 \%$ SR & 325 & 18.4 & 52.3 & 54.2 & 4.48 & 4.15 & 4.47 & 4.37 \\
\hline CV (\%) & 11.34 & 5.34 & 7.59 & 3.65 & 5.65 & 10.24 & 9.67 & 7.25 \\
\hline $\operatorname{LSD}_{(0.05)}$ & 13.25 & ns & 0.231 & ns & 0.153 & 0.175 & 0.312 & 0.231 \\
\hline
\end{tabular}

PB-Permanent bed, ST- Strip tillage 
Grain yield was higher due to higher yield attributes, more tillering and border effect with sunlight. Talukderet al. (2004) found more yield from both permanent and strip till system. Minimum grain yield $\left(3.61 \mathrm{t} \mathrm{ha}^{-1}\right.$ ) was also found from conventional planting with $0 \%$ residue retention. Minimum grain yield was also found by Talukderet al. (2002) from same treatments.Yield components were significantly influenced among the residue retention under different tillage options. Maximum spike $\mathrm{m}^{-}$ 2 (325) was found from $30 \%$ residue retention with fresh bed systems followed by (321) from permanent bed system with $30 \%$ residue retention. Maximum grains spike ${ }^{-1}$ (52.4) was obtained from $30 \%$ straw retention with PB followed by (52.3) from ST with $30 \%$ residue retention. Talukderet al. (2004) found more spike $\mathrm{m}^{-2}$ and grains spike ${ }^{-1}$ from both permanent and strip till system. Minimum spike (311) and grains spike $^{-1}$ (48.2) obtained from $0 \%$ residue retention with conventional tillage practices.

\section{Maize grain yield and components under different tillage options}

The effect of different levels of tillage options had significant on all yield attributes and grain yield of maize (Table 5). Shifting from conventional to strip till and permanent bed resulted in significant yield increase of maize, which attributed from higher numbers of cobs $\mathrm{m}^{-2}$, cob length and grains $\mathrm{cob}^{-1}$. Both strip till and permanent bed produced higher grain yield over conventional tillage. Both strip till and permanent bed equally better in respect of improving cobs $\mathrm{m}^{-2}$, grains $\mathrm{cob}^{-1}$, thousand grain weightsbut not significant and thereby produced higher grain yield of maize. Average two years yield data were shown in Table 5,the maximum grain yield was found $\left(7.34 \mathrm{t} \mathrm{ha}^{-1}\right)$ was found from strip till systems and it was at par $\left(7.31 \mathrm{t} \mathrm{ha}^{-1}\right)$ in case of permanent bed system. Lauren et al. (2006) found more yield from both permanent and fresh bed system.

Table 5. Maize grain yield and yield attributes affected by tillage options

\begin{tabular}{|c|c|c|c|c|c|c|c|}
\hline \multirow{2}{*}{ Tillage options } & \multirow[b]{2}{*}{$\begin{array}{c}\text { Cobs } \\
\mathrm{m}^{-2}\end{array}$} & \multirow{2}{*}{$\begin{array}{l}\text { Cob } \\
\text { length } \\
(\mathrm{cm})\end{array}$} & \multirow[b]{2}{*}{$\begin{array}{c}\text { Grains } \\
\mathrm{Cob}^{-1}\end{array}$} & \multirow[b]{2}{*}{$\begin{array}{c}\text { TGW } \\
(\mathrm{g})\end{array}$} & \multicolumn{2}{|c|}{ Grain yield $\left(\mathrm{t} \mathrm{ha}^{-1}\right)$} & \multirow{2}{*}{$\begin{array}{c}\text { Av. } 2 \text { years } \\
\text { yield } \\
\left(\mathrm{t} \mathrm{ha}^{-1}\right)\end{array}$} \\
\hline & & & & & $2015-16$ & $2016-17$ & \\
\hline Conventional & 8.71 & 16.7 & 372.5 & 231.4 & 6.89 & 6.97 & 6.93 \\
\hline Permanent bed & 9.56 & 17.4 & 417.7 & 233.5 & 7.19 & 7.42 & 7.31 . \\
\hline Strip tillage & 9.48 & 17.3 & 419.8 & 230.6 & 7.33 & 7.35 & 7.34 \\
\hline $\mathrm{CV}(\%)$ & 9.35 & 7.54 & 9.75 & 7.87 & 8.65 & 9.21 & 7.85 \\
\hline $\mathrm{LSD}_{(0.05)}$ & 0.231 & ns & 0.231 & ns & 0.112 & 0.121 & 0.114 \\
\hline
\end{tabular}

\section{Maize grain yield and components under different straw retention}

The effect of different levels of straw retentionhad significant on all yield attributes and grain yield of maize (Table 6). Shifting from without straw retention to $30 \%$ residue retention resulted in nonsignificant yield increase of maize. Both straw retention equally better in respect of improving cobs $\mathrm{m}^{-}$ ${ }^{2}$, grains $\mathrm{cob}^{-1}$, thousand grain weights but not significant and thereby produced higher grain yield of maize. Average two years yield data were shown in Table 6, the maximum grain yield was found (7.39 $\mathrm{t} \mathrm{ha}^{-1}$ ) was found from $30 \%$ straw retention plot and it was similar to without straw retention plot. RWC-CIMMYT (2003) found similar results from their experiments under residue retention.

Table 6. Maize grain yield and yield attributes affected by straw retention

\begin{tabular}{|c|c|c|c|c|c|c|c|}
\hline \multirow{2}{*}{$\begin{array}{c}\text { Straw } \\
\text { retention }\end{array}$} & \multirow{2}{*}{$\begin{array}{c}\text { Cobs } \\
\mathrm{m}^{-2}\end{array}$} & \multirow{2}{*}{$\begin{array}{c}\text { Cob } \\
\text { length } \\
(\mathrm{cm}) \\
\end{array}$} & \multirow{2}{*}{$\begin{array}{l}\text { Grains } \\
\mathrm{Cob}^{-1}\end{array}$} & \multirow[b]{2}{*}{$\begin{array}{c}\text { TGW } \\
(\mathrm{g})\end{array}$} & \multicolumn{2}{|c|}{ Grain yield $\left(\mathrm{t} \mathrm{ha}^{-1}\right)$} & \multirow{2}{*}{$\begin{array}{c}\text { Av. } 2 \text { years } \\
\text { yield } \\
\left(\mathrm{t} \mathrm{ha}^{-1}\right)\end{array}$} \\
\hline & & & & & $2015-16$ & $2016-17$ & \\
\hline $0 \% \mathrm{SR}$ & 9.21 & 16.9 & 379.2 & 237.4 & 7.04 & 7.11 & 7.07 \\
\hline $30 \% \mathrm{SR}$ & 9.47 & 17.1 & 423.3 & 239.5 & 7.29 & 7.49 & 7.39 \\
\hline $\mathrm{T}$ test & ns & ns & 9.44 & ns & ns & 9.35 & 7.15 \\
\hline
\end{tabular}




\section{Maize grain yield and yield attributes from the treatments}

The cumulative effect of different levels of tillage options and straw retention had significant on all yield attributes and grain yield of maize (Table 7). Shifting from conventional to strip till and permanent bed resulted in significant yield increase of maize, which attributed from higher numbers of cobs $\mathrm{m}^{-2}$, cob length and grains $\mathrm{cob}^{-1}$. Both strip till and permanent bed produced higher grain yield over conventional tillage but straw retention did not get any significant effect on yield and yield attributes. Conventional tillage with both 0 and $30 \%$ straw retention reduced the yield over strip till and permanent bed with straw retention. Both strip till and permanent bed equally better in respect of improving cobs $\mathrm{m}^{-2}$, grains $\mathrm{cob}^{-1}$, thousand grain weight and thereby produced higher grain yield of maize. Average two years yield data were shown in Table 4. The maximum grain yield was found (7.40 $\mathrm{t} \mathrm{ha}^{-1}$ ) was found from $30 \%$ residue retention with strip till systems and it was at par $\left(7.39 \mathrm{tha}^{-1}\right)$ in case of permanent bed system with $30 \%$ residue retention. Grain yield was higher due to higher yield attributes whereas more border effect with sunlight. Sayre et al. (2005) found more yield from both permanent and fresh bed system. Minimum grain yield $\left(6.93 \mathrm{t} \mathrm{ha}^{-1}\right)$ was also found from conventional tillage with $0 \%$ residue retention. On the contrary, minimum grain yield was found by Limon Ortega $e t$ al. (2004) from both permanent and fresh bed system. Yield attributes were significantly influenced among the residue retention under different tillage options. Maximum cob $\mathrm{m}^{-2}$ (9.63) was found from $30 \%$ residue retention with permanent bed systems followed by (9.53) that of strip till system with $30 \%$ residue retention.

Table 7. Interaction effect of tillage options and straw management on grain yield and yield attributes ofKharif 1 maize in 2015-16 to 2016-17

\begin{tabular}{lccccccc}
\hline $\begin{array}{c}\text { Tillage options } \\
\text { x straw retention }\end{array}$ & $\begin{array}{c}\text { Cobs } \\
\mathrm{m}^{-2}\end{array}$ & $\begin{array}{c}\text { Cob } \\
\text { length } \\
(\mathrm{cm})\end{array}$ & $\begin{array}{c}\text { Grains } \\
\mathrm{cob}^{-1}\end{array}$ & $\begin{array}{c}\text { TGW } \\
(\mathrm{g})\end{array}$ & \multicolumn{2}{c}{ Grain yield $\left(\mathrm{t} \mathrm{ha}^{-1}\right)$} & $\begin{array}{c}\text { Av. 2 years } \\
\text { yield } \\
\left(\mathrm{t} \mathrm{ha}^{-1}\right)\end{array}$ \\
\hline Conv x 0 \% SR & 8.71 & 16.7 & 372.5 & 231.4 & 6.89 & 6.97 & 6.93 \\
Conv x 30 \% SR & 8.78 & 16.9 & 388.4 & 229.8 & 6.92 & 7.21 & 7.07 \\
PB x 0 \% SR & 9.56 & 17.4 & 417.7 & 233.5 & 7.19 & 7.42 & 7.31 \\
PB x 30 \% SR & 9.63 & 17.2 & 432.3 & 231.7 & 7.13 & 7.64 & 7.39 \\
ST x 0 \% SR & 9.48 & 17.3 & 419.8 & 230.6 & 7.33 & 7.35 & 7.34 \\
ST x 30 \% SR & 9.53 & 17.5 & 427.4 & 229.9 & 7.21 & 7.58 & 7.40 \\
\hline CV $(\%)$ & 9.35 & 7.54 & 9.75 & 7.87 & 8.65 & 9.21 & 7.85 \\
\hline LSD $_{(0.05)}$ & 0.121 & ns & 1.345 & ns & 0.425 & 0.542 & 0.526 \\
\hline
\end{tabular}

PB-Permanent bed, ST- Strip tillage

Maximum grains per cob (427.4) was obtained from 30\% straw retention with ST followed by (432.3) from PB with 30\% residue retention. Limon Ortega et al. (2004) found more cob $\mathrm{m}^{-2}$ and grains cob from both permanent and fresh bed system. Minimum cob $\mathrm{m}^{-2}$ (8.71) and grains per cob (372.5) obtained from $0 \%$ residue retention with conventional tillage practices. Sayre et al. (2005) found similar findings from their experiments under permanent and fresh bed system.

\section{Rice yield and yield components on different tillage options}

The rice crop was non-puddled transplanted both fresh and permanent bed but puddle transplanted in conventional tillage method had non-significant effect of conservation agriculture practices which imposed in previous wheat and maize crops were induced in rice crop. The effect of different levels of tillage options had significant on panicles hill $^{-1}$, grains panicle ${ }^{-1}$ and 1000 grain weight but nonsignificant on hill $\mathrm{m}^{-1}$ and grain yield of rice. Singh et al.(2003) found similar findings from their experiments. The transplanted Amanrice was cultivated under the saturated to submerge soil conditions and the residual effect of CA did not resulted in significant impact on rice grain yield (Table 8). Only number of grains panicle ${ }^{-1}$ influenced by the treatments and both fresh and permanent bed produced higher grains panicle ${ }^{-1}$. Maximum grain yield $\left(4.40\right.$ tha $\left.^{-1}\right)$ was found from permanent bed systems and 
at par with fresh bed systems.

Table 8. Yield and yield components of rice as affected from different tillage options in 2015-16 to 2016-17

\begin{tabular}{|c|c|c|c|c|c|c|c|}
\hline \multirow[t]{2}{*}{ Tillage options } & \multirow{2}{*}{$\begin{array}{l}\text { Hills } \\
\mathrm{m}^{-2}\end{array}$} & \multirow{2}{*}{$\begin{array}{c}\text { Panicles } \\
\text { hill }^{-1}\end{array}$} & \multirow{2}{*}{$\begin{array}{c}\text { Grains } \\
\text { panicle }^{-1}\end{array}$} & \multirow{2}{*}{$\begin{array}{l}\text { TGW } \\
(\mathrm{g})\end{array}$} & \multicolumn{2}{|c|}{ Grain yield $\left(\mathrm{t} \mathrm{ha}^{-1}\right)$} & \multirow{2}{*}{$\begin{array}{l}\text { Av. } 2 \text { years } \\
\text { yield }\left(\mathrm{t} \mathrm{ha}^{-1}\right)\end{array}$} \\
\hline & & & & & $2015-16$ & 2016-17 & \\
\hline Conventional & 29.2 & 17.6 & 130.7 & 24.3 & 4.34 & 4.12 & 4.23 \\
\hline Permanent bed & 30.7 & 18.4 & 135.2 & 25.1 & 4.47 & 4.32 & 4.40 \\
\hline Strip tillage & 30.4 & 18.2 & 134.8 & 24.9 & 4.41 & 4.29 & 4.35 \\
\hline $\mathrm{CV}(\%)$ & 7.25 & 8.45 & 8.785 & 9.75 & 9.87 & 10.37 & 8.325 \\
\hline $\operatorname{LSD}_{(0.05)}$ & ns & 0.325 & 1.225 & 0.112 & ns & ns & ns \\
\hline
\end{tabular}

\section{Rice yield and yield components on different residue retention}

Straw management had non-significant effect of conservation agriculture practices in rice crop. The effect of different levels of residue retention had significant on grains panicle ${ }^{-1}$ and 1000 grain weight but non-significant on hill $\mathrm{m}^{-1}$, panicle hill ${ }^{-1}$ and grain yield of rice. Singh et al.(2003) found similar findings from their experiments. The transplanted Amanrice was cultivated under the saturated to submerge soil conditions and the residual effect of CA did not resulted in significant impact on rice grain yield (Table 9). Only number of grains panicle ${ }^{-1}$ and 1000 grain weight influenced by straw retention plot produced higher grain yield but non-significant. Maximum grain yield (4.69 tha $^{-1}$ ) was found from $30 \%$ straw retention plot and at par with $0 \%$ straw retention plot.

Table 9. Yield and yield components of rice as affected from different straw management plot in 201516 to $2016-17$

\begin{tabular}{lccccccc}
\hline \multirow{2}{*}{ Straw retention } & Hills & Panicles & Grains & TGW & \multicolumn{2}{c}{ Grain yield $\left(\mathrm{t} \mathrm{ha}^{-1}\right)$} & Av. 2 years \\
& $\mathrm{m}^{-2}$ & hill $^{-1}$ & panicle $^{-1}$ & $(\mathrm{~g})$ & $2015-16$ & $2016-17$ & yield $\left(\mathrm{t} \mathrm{ha}^{-1}\right)$ \\
\hline $0 \% \mathrm{SR}$ & 32.2 & 18.1 & 130.5 & 24.4 & 4.52 & 4.47 & 4.49 \\
$30 \% \mathrm{SR}$ & 33.7 & 18.8 & 136.7 & 25.5 & 4.67 & 4.72 & 4.69 \\
\hline T-Test & $\mathrm{ns}$ & $\mathrm{ns}$ & $*$ & $*$ & $\mathrm{~ns}$ & $\mathrm{~ns}$ & $\mathrm{~ns}$ \\
\hline
\end{tabular}

\section{Rice yield and yield components as interaction effect of tillage option and residue retention}

The rice crop was non-puddled transplanted both fresh and permanent bed but puddle transplanted in conventional tillage method but only the residual effect of CA practices which imposed in previous wheat and maize crops were induced in rice. The cumulative effect of different levels of tillage options and straw retention had significant on panicles hill ${ }^{-1}$, grains panicle ${ }^{-1}$ and 1000 grain weight but nonsignificant on hill $\mathrm{m}^{-1}$ and grain yield of rice. Singh (2003) found similar findings from their experiments. The transplanted amanrice was cultivated under the saturated to submerge soil conditions and the residual effect of CA did not resulted in significant impact on rice grain yield (Table 10). Only number of grains panicle ${ }^{-1}$ influenced by the treatments and both fresh and permanent bed produced higher grains panicle ${ }^{-1}$. Maximum panicle hill $^{-1}(31.4)$ was found from $30 \%$ SR with permanent bed systems and at par with $30 \%$ SR with fresh bed systems. Maximum grains panicle ${ }^{-1}$ (136.3) was obtained from $30 \%$ SR with permanent bed systems and at par with 30\% SR with fresh bed systems. Yadvinderet al. (2005) found non-significant effect under different tillage options with residue retention about four years. However, all the benefit of cropping systems and the intervention of CA practices may not be notice within two years cycle. Long term study is necessary to understand the treatments effects on productivity of component crops in the systems. 
Table 10. Yield and yield components of rice crop as interaction effect of different tillage options and straw retention in 2015-16 to 2016-17

\begin{tabular}{lccccccc}
\hline $\begin{array}{c}\text { Tillage options } \\
\text { x straw retention }\end{array}$ & Hills & Panicles & Grains & TGW & \multicolumn{2}{c}{ Grain yield (t ha $\left.{ }^{-1}\right)$} & \multirow{2}{*}{$\begin{array}{c}\text { Av. 2 years } \\
\text { yield }\left(\mathrm{t} \mathrm{ha}^{-1}\right)\end{array}$} \\
\hline Conv. x 0 \% SR & 29.2 & 17.6 & 130.7 & 24.3 & 4.34 & 4.12 & 4.23 \\
Conv. x 30 \% SR & 28.8 & 17.9 & 132.3 & 24.7 & 4.23 & 4.19 & 4.21 \\
PB x 0 \% SR & 30.7 & 18.4 & 135.2 & 25.1 & 4.47 & 4.32 & 4.40 \\
PB x 30 \% SR & 31.4 & 18.8 & 136.3 & 25.4 & 4.53 & 4.37 & 4.45 \\
ST x 0 \% SR & 30.4 & 18.2 & 134.8 & 24.9 & 4.41 & 4.29 & 4.35 \\
ST x 30 \% SR & 30.9 & 18.5 & 135.2 & 25.2 & 4.49 & 4.41 & 4.45 \\
\hline CV (\%) & 7.25 & 8.45 & 8.785 & 9.75 & 9.87 & 10.37 & 8.325 \\
\hline LSD $_{(0.05)}$ & $\mathrm{ns}$ & 0.325 & 1.225 & 0.112 & $\mathrm{~ns}$ & $\mathrm{~ns}$ & $\mathrm{~ns}$ \\
\hline
\end{tabular}

\section{Soil properties}

After 3 cycles (years) both raised bed strip tillage options of soil condition was improved (Table 11). Soil $\mathrm{pH}$, organic matter content, total $\mathrm{N}$, available $\mathrm{P}$, exchangeable $\mathrm{K}$ and $\mathrm{Mg}$ were found higher in both raised bed tillage options than conventional tillage. After 3 years crop cycles, retention of straw from all three crops in the both tillage systems had increased the soil organic matter by $0.12-0.14 \%$. Since the both raised bed and strip tillage options produced more biomass in $30 \%$ crop residues from all crops were kept in the soil properties were improved. While some of the increase may have been due to formation of the beds from topsoil, the change in organic $\mathrm{C}$ increased as the rate of residue retention increased from $30 \%$, indicating that straw retention also affected organic $\mathrm{C}$ on the beds. $\mathrm{P}, \mathrm{K}$ and $\mathrm{Zn}$ availability increased due to $30 \% \mathrm{SR}$ with PRB. After 3 years of CTP without residues, soil organic C had decreased by a few percent. Kumar and Goh (2000) reported that, in the longer term, residues and untilled roots from crops can contribute to the formation of SOM. After three years crop cycles, soil condition in permanent raised bed tillage options was better than conventional tillage.

Table 11. Soil chemical properties analyzed after three years crop cycle

\begin{tabular}{|c|c|c|c|c|c|c|c|c|}
\hline $\begin{array}{c}\text { Tillage } \\
\text { x SR }\end{array}$ & $\mathrm{pH}$ & $\begin{array}{c}\text { Organic } \\
\text { matter } \\
(\%) \\
\end{array}$ & $\begin{array}{l}\text { Total } \\
\mathrm{N}(\%)\end{array}$ & $\begin{array}{c}\text { Available } \\
\mathrm{P}(\mu \mathrm{g} \mathrm{g}- \\
\left.{ }^{1} \text { soil }\right) \\
\end{array}$ & $\begin{array}{l}\text { Exchangeable } \\
\mathrm{K} \text { (meq100g- }{ }^{1} \\
\text { soil) }\end{array}$ & $\begin{array}{c}\text { Available } \\
\text { S(mgg- } \\
\left.{ }^{1} \text { soil }\right) \\
\end{array}$ & $\begin{array}{c}\mathrm{Zn} \\
\left(\mu \mathrm{g} \mathrm{g}-{ }^{1}\right. \\
\text { soil }) \\
\end{array}$ & $\begin{array}{c}\mathrm{B} \\
\left(\mu \mathrm{g} \mathrm{g}^{1}{ }^{1}\right. \\
\text { soil }) \\
\end{array}$ \\
\hline Conv. X $0 \%$ SR & 7.8 & 0.92 & 0.06 & 11.3 & 0.23 & 23.5 & 0.15 & 0.28 \\
\hline Conv. X $30 \%$ SR & 8.0 & 0.98 & 0.07 & 13.5 & 0.25 & 24.2 & 0.17 & 0.31 \\
\hline $\mathrm{PB} \times 0 \% \mathrm{SR}$ & 7.9 & 0.93 & 0.08 & 11.8 & 0.24 & 23.7 & 0.14 & 0.27 \\
\hline PB X30\% SR & 8.1 & 1.06 & 0.08 & 14.2 & 0.27 & 24.9 & 0.19 & 0.35 \\
\hline ST X $0 \%$ SR & 7.8 & 0.94 & 0.07 & 11.5 & 0.22 & 23.6 & 0.15 & 0.27 \\
\hline ST X $30 \%$ SR & 8.2 & 1.04 & 0.08 & 13.8 & 0.26 & 24.8 & 0.18 & 0.34 \\
\hline
\end{tabular}

\section{Economic Evaluation of Conservation Agriculture (CA)}

For economic evaluation, considered 20 farmers for permanent bed and 25 farmers for strip tillage in both the cases. From Table 12, observed that total 25\% cost saved of Taman rice production in PRB and $17 \%$ cost saved in new bed over farmers practice as well as more than double net return from both permanent and new bed system over farmers practice (FP). It also observed that economically higher return from both PRB (28\%) and new beds (34\%) than FP. However, CA is more economically viable than farmers practice. Singh and Singh(1995) found similar results from their experimental field. 
Table 12. Economic Performance of CA for Taman rice in 2012-16 farmers

\begin{tabular}{lcccccc}
\hline \multirow{2}{*}{ Factors } & \multicolumn{3}{c}{ Permanent $(\mathrm{n}=20)$} & \multicolumn{3}{c}{ Strip tillage $(\mathrm{n}=25)$} \\
\cline { 2 - 7 } & Bed & FP & Change & Strip till & FP & Change \\
\hline Tillage/land preparation & 250 & 480 & $-47 \%$ & 220 & 480 & $54 \%$ \\
Seed & 140 & 200 & $-30 \%$ & 140 & 200 & $-30 \%$ \\
Fertilizer \& Pest & 650 & 780 & $-16 \%$ & 650 & 780 & $-16 \%$ \\
Management & & & & & & \\
Irrigation & 450 & 760 & $-40 \%$ & 480 & 760 & $-36 \%$ \\
Weeding & 395 & 550 & $-26 \%$ & 420 & 550 & $-26 \%$ \\
Harvest & 510 & 5600 & $-9 \%$ & 520 & 560 & $-7 \%$ \\
Threshing & 230 & 200 & & 230 & 200 & \\
Total Costs & 2625 & 3530 & $-25 \%$ & 2920 & 3530 & $-17 \%$ \\
Yield (kg bigha $\left.{ }^{-1}\right)$ & 760 & 590 & $28 \%$ & 795 & 590 & $34 \%$ \\
Value \&Tk 10 kg & 7600 & 5900 & $28 \%$ & 7950 & 5900 & $34 \%$ \\
Net Return & 4975 & 2370 & 2605 & 5030 & 2370 & 2660 \\
& & & $(2.1 \mathrm{X})$ & & & $(2.12 \mathrm{X})$ \\
\hline
\end{tabular}

\section{Conclusion}

Yield of component crops with in an intensive wheat-maize-rice cropping pattern was achieved under different tillage options. From the study it revealed that both tillage systems affected in terms of yield and yield components which ultimately produced maximum yield due to its more photosynthesis and border effect. Soil organic matter in surface soil had increased by $0.14 \%$ after 3 years crop cycles with $30 \%$ SR from rice, wheat and maize crops. Straw retention is an important component of soil management and may have long term positive impacts on soil quality. Both strip tillage and permanent raised bed systems with $30 \%$ residues retained appears to be a very promising technology for sustainable intensification of RWM systems in drought prone areas of Bangladesh.

\section{References}

BARC (Bangladesh Agricultural Research Council). Fertilizer recommendation guide, 2012. pp.10-12.

Connor D.J., J. Timsina and E. Humphreys. 2002. Prospects for permanent beds for the rice-wheat system. In: 'Improving the productivity and sustainability of rice-wheat systems: issues and impacts' (J.K. Ladha, J.E. Hill, J.M. Duxbury, R.K. Gupta and R.J. Buresh Eds.). Vol. 65, pp.197-210. ASA Special Publication, ASA Inc., Madison, WI.

Gomez, K.A. and A.A. Gomez. 1984. Statistical Procedures for Agricultural Research (Second edition).John Wiley \& Sons, Inc., IRRI, Philippines, 680p.

Gupta, R.K., R.K. Naresh, P.R. Hobbs and J.K. Ladha. 2002. Adopting Conservation Agriculture in RiceWheat Systems of the Indo-Gangetic Plains- New Opportunities for Saving on Water. Paper presented at the Water Wise Rice Production Workshop", 5-10 April 2002, IRRI, Philippines.

Hobbs P.R. and G.S. Giri. 1998. Reduced and zero-tillage options for establishment of wheat after rice in South Asia. In 'Wheat prospects for global improvement by H. J. Braun, Kluwer Academic Press, Dordrecht, The Netherlands.

Hobbs, P.R and R.K Gupta. 2000. 'Soil and Crop Management Practices for Enhanced Productivity of the Rice-Wheat Cropping System in the Sichuan Province of China. Rice-Wheat Consortium Paper Series 9. (RWC, New Delhi, India).

Kataki, P.K. 2001. The rice-wheat cropping system in South: Trends, Constraints and Productivity- A Prologue, J. Crop Prod. 3: 1-26. 
Kumar, K. and K.M. Goh. 2000. Crop residue management, effects on soil quality, soil nitrogen dynamics, crop yield and nitrogen recovery. Adv. Agron. 68: 197-319.

Lauren, J.G., J.M. Duxbury, M.I. Hossain, G. Sah, A.S.M.H.M. Talukder and C.A. Meisner. 2006. Permanent raised bed cultivation improves nitrogen and Water use in rice-wheat cropping systems of South Asia. 10th World Science Congress, USA.

Limon-Ortega, A.L., K.D. Sayre and C.A. Francis. 2000. Wheat nitrogen use efficiency in a bed planting system in Northwest Mexico. Agron. J. 92: 303-308.

Limon-Ortega, A.L., K.D. Sayre and C.A. Francis. 2004. Wheat and maize yields in response to strawmanagement and nitrogen under a bed planting system. Agron. J. 92: 295-302.

Quayyum, M.A., J. Timsina, M.A.H.S. Jahan, R.A. Begum and D.J. Connor. 2002. Grain yield and system productivity for wheat-mungbean-rice and wheat-maize rice sequences in northern Bangladesh. Thai J. Agric. Sci. 35: 51-62.

RWC-CIMMYT. 2003. Addressing Resource Conservation Issues in Rice-Wheat Systems of South Asia: A Resource Book. (RWC-CIMMYT, New Delhi, India).

Sayre, K.D., A. Limon and B. Govaerts. 2005. Experiences with permanent bed planting systems. byRoth, C.H., Fischer, R.A., Meisner, C.A. (Eds.). Evaluation and Performance of Permanent Raised Bed Cropping Systems in Asia, Australia and Mexico,Proceedings of a Workshop, Griffith, Australia, 1-3 March 2005. ACIAR Proceedings No. 121, pp.12-25.

Singh, Y. 2003. Crop Residue management in rice-wheat system. 2003. In: Addressing Resource Conservation Issues in Rice-Wheat Consortium for the Indo-Gangetic Plains.CIMMYT, New Delhi, India, p.153.

Singh, H. and K.P. Singh. 1995. Effect of plant residue and fertilizer on grain yield of dryland rice under reduced tillage cultivation. Soil Till. Res. 34: 115-125.

Talukder, A.S.M.H.M., C.A. Meisner, M.J. Kabir, A.B.S. Hossain and M. Harun-ur-Rashid. 2004. Productivity of multi-crops sown on permanent raised beds in the tropics. In: New Direction for a Diverse Planet: Handbook and Abstracts for the 4thInternational Crop Science Congress, Brisbane, Australia, 26 September - 01 October 2004, p.173.

Talukder, A.S.M.H.M., M.A. Sufian and C.A. Meisner. 2002. Rice, wheat and mungbean yields in response to $\mathrm{N}$ levels and management under a bed planting system. In: Proceedings published in the 17thWorld Congress of Soil Science, Bangkok, Thailand, v. 1, Symposium no. 11, p..351.

Timsina, J. and D.J.Connor. 2001. Productivity and management of rice-wheat cropping systems: issues and challenges. Field Crops Res. 69: 93-132.

Yadvinder, S., S. Bijay and J. Timsina. 2005. Crop residue management for nutrient cycling and improving soil productivity in rice-based cropping systems in the tropics. Adv. Agron. 85:269- 407. 